Article

\title{
Comparison of Diatoms and Dinoflagellates from Different Habitats as Sources of PUFAs
}

\author{
Elina Peltomaa ${ }^{1,2,3, * \mathbb{C}}$, Heidi Hällfors ${ }^{4}$ and Sami J. Taipale ${ }^{5, *}$ \\ 1 Faculty of Biological and Environmental Sciences, Ecosystems and Environment Research Programme, \\ University of Helsinki, Niemenkatu 73, FI-15140 Lahti, Finland \\ 2 Institute of Atmospheric and Earth System Research (INAR)/Forest Sciences, University of Helsinki, P.O. Box \\ 27, FI-00014 Helsinki, Finland \\ 3 Helsinki Institute of Sustainability Science (HELSUS), Yliopistonkatu 3, FI-00014 Helsinki, Finland \\ 4 Finnish Environment Institute, Marine Research Centre, Marine Ecological Research Laboratory, Agnes \\ Sjöbergin katu 2, FI-00790 Helsinki, Finland; heidi.hallfors@ymparisto.fi \\ 5 Department of Biological and Environmental Science, University of Jyväskylä, P.O. Box 35 (YA), 40014 \\ Jyväskylä, Finland \\ * Correspondence: elina.peltomaa@helsinki.fi (E.P.); sami.taipale@jyu.fi (S.J.T.); Tel.: +358-50-448-6649 (E.P.); \\ $+358-50-351-6261$ (S.J.T.)
}

Received: 20 March 2019; Accepted: 17 April 2019; Published: 19 April 2019

check for updates

\begin{abstract}
Recent studies have clearly shown the importance of omega-3 ( $\omega-3)$ and omega-6 ( $\omega-6)$ polyunsaturated fatty acids (PUFAs) for human and animal health. The long-chain eicosapentaenoic acid (EPA; 20:5w-3) and docosahexaenoic acid (DHA; 22:6w-3) are especially recognized for their nutritional value, and ability to alleviate many diseases in humans. So far, fish oil has been the main human source of EPA and DHA, but alternative sources are needed to satisfy the growing need for them. Therefore, we compared a fatty acid profile and content of 10 diatoms and seven dinoflagellates originating from marine, brackish and freshwater habitats. These two phytoplankton groups were chosen since they are excellent producers of EPA and DHA in aquatic food webs. Multivariate analysis revealed that, whereas the phytoplankton group (46\%) explained most of the differences in the fatty acid profiles, habitat (31\%) together with phytoplankton group (24\%) explained differences in the fatty acid contents. In both diatoms and dinoflagellates, the total fatty acid concentrations and the $\omega-3$ and $\omega-6$ PUFAs were markedly higher in freshwater than in brackish or marine strains. Our results show that, even though the fatty acid profiles are genetically ordered, the fatty acid contents may vary greatly by habitat and affect the $\omega-3$ and $\omega-6$ availability in food webs.
\end{abstract}

Keywords: microalgae; diatoms; dinoflagellates; marine; brackish; freshwater; polyunsaturated fatty acids; EPA; DHA

\section{Introduction}

Microalgae have been recognized as a source of functional ingredients for nutraceuticals with positive health effects, since they are able to synthetize many compounds essential for human nutrition [1,2]. Microalgae can be grown in controlled conditions, allowing the production of biomass with a constant biochemical composition and eliminating the risk of chemical contamination of the biomass. In the past few decades, the long-chain polyunsaturated omega-3 fatty acids ( $\omega-3$ PUFAs) have been recognized as compounds of great physiological importance for humans and other consumers [3]. In humans, eicosapentaenoic acid (EPA; 20:5w-3) and docosahexaenoic acid (DHA; 22:6w-3) are needed for the formation of eicosanoids, resolvins and protectins, which protect our cardiovascular system and alleviate e.g., renal diseases, inflammation, depression and tumor activity [4,5]. EPA and DHA are also essential for normal fetal brain development as well as growth and development of infants 
and children [3-6]. In aquatic ecosystems, the availability of $\omega-3$ PUFAs has been related to egg production and hatching success of marine copepods [7,8] and freshwater cladocerans [9], as well as on the survival of fish larvae [10].

Most EPA and DHA are synthesized in aquatic environments, since terrestrial plants can only synthesize their precursors alpha-linolenic acid (ALA; 18:3 $\omega-3$ ) and stearidonic acid (SDA, 18:4 $\omega-3)[2,11]$. Some vertebrates can convert EPA and DHA from ALA and SDA through desaturation and elongation processes, but the conversion efficiency is generally low among vertebrates, including humans (e.g., in humans 1-4\% [12,13]). Previous studies have shown that EPA and DHA synthesis is common only among some microalgal taxa [14-16]. Thus, the supply of the $\omega-3$ PUFAs is dependent on the algal species composition in the aquatic food webs $[16,17]$. The amount of $\omega-3$ PUFAs in the phytoplankton community is reflected to the upper trophic levels, ultimately affecting the nutritional quality of fish to humans $[18,19]$.

In addition to $\omega-3$ PUFAs, omega-6 ( $\omega-6)$ PUFAs are also considered essential, but an excess dietary gain of $\omega-6$ is related to negative health implications $[5,20]$. Excess $\omega-6$, e.g., promote cardiovascular diseases, diabetes, cancer and inflammatory and autoimmune diseases in humans [20-26]. The main dietary sources of $\omega-6$ PUFAs include plant oils such as sunflower, safflower, and corn oils, but they are also present in animal fat and wholegrain bread [5]. In the Western diet, the $\omega-6$ PUFA consumption has become too high compared to $\omega-3$ PUFAs due to increased consumption of linoleic acid (LA; 18:2 $\omega-6$ ) and arachidonic acid (ARA; 20:4w-6), which are precursors of the long-chain $\omega-6$ PUFAs [22,23]. The optimal dietary $\omega-6: 3$-ratio is around 1 to $4: 1$, but in the Western diet the ratio varies between 10:1 and 20:1 [25]. This is significant, since $\omega-3$ and $\omega-6$ elongation uses the same enzymes, and thus in humans the excess consumption $\omega-6$ fatty acids reduces the already low conversion rate of short chain ALA to long-chain EPA and DHA by $40-50 \%$ [26]. In some microalgae, the $\omega-6: 3$-ratios are reported to be well below the suggested dietary $\omega-6: 3$-ratio and thus microalgae could be especially suitable for products designed for balancing the dietary $\omega-6: 3$-ratios [27].

Since EPA and DHA are primarily produced and transferred in the food chains of the aquatic environments, the demand for fish and seafood has constantly increased for filling the needs of the ever-growing human population [28]. Furthermore, over half of all fish and seafood is now being farmed and the only way to ensure high levels of EPA and DHA in farmed fish is to include these fatty acids in their feed [3,29]. Traditionally, this has been done by adding fish or fish oil into fish feed. Alternative sources are, however, needed because fish stock harvests cannot satisfy the consumer needs, and also the practice of using wild fish as feed at fish farms is unsustainable. As aquaculture and the required feed volumes have expanded, fish oil has been increasingly replaced by vegetable oils lacking EPA and DHA, but often containing high levels of $\omega-6$ PUFAs [29]. This strategy has increased the sustainability of aquaculture, but impacted the nutritional quality of farmed fish that obtain less EPA and DHA and more $\omega-6$ PUFAs than previously [30]. As a consequence, the amount of EPA and DHA has halved in farmed Atlantic salmon in 2006-2015 [31].

Based on previous studies, diatoms are known to be rich in EPA and dinoflagellates in DHA [14-17]. Both of them represent major groups of microalgae found in all kinds of aquatic habitats from oceans to brackish and freshwater environments, and their role in aquatic carbon and nutrient cycles is significant. Thus, they are both nutritionally important in different aquatic food webs and should offer great potential for commercial production of $\omega-3$ PUFAs. However, in marine and brackish environments, some diatoms and dinoflagellates are known to be toxin producers, which obviously reduces their suitability for food and feed products [32]. Therefore, the commercial scale production of EPA and DHA from microalgae need to overcome several challenges starting from the screening and selection of strains [33].

Previous studies [14-17] have shown that the fatty acid profiles of algae are genetically determined, and, thus, when given as percentages of total fatty acids, more or less similar within taxonomical groups in marine and freshwater environments. However, fatty acid contents (as $\mu \mathrm{g}$ fatty acids per $\mathrm{mg}$ dry weight) are rarely reported, and thus it is not yet known whether the fatty acid contents resemble 
each other in the marine, brackish and freshwater strains. This can be misleading when considering the actual availability of the essential fatty acids in the food webs. Therefore, we cultured 10 diatoms and seven dinoflagellates of different habitats (marine, brackish, freshwater) and used multivariate statistical analysis to define the impact of habitat in fatty acid profiles and content in addition to phylogeny. In this study, we especially focused on comparing the $\omega-3$ and $\omega-6$ fatty acid content of diatoms and dinoflagellates originating from marine, brackish and freshwater habitats. This is the first attempt to study if the content of the bioactive $\omega-3$ and $\omega-6$ fatty acids varies systematically based on habitat. We did not study the toxicity of the strains, but-based on literature- the strains selected included both potentially toxic and non-toxic species.

We hypothesized that phylogeny is the main factor influencing the fatty acid profiles and contents of diatoms and dinoflagellates including the $\omega-3$ and $\omega-6$. We also selected three strain pairs, i.e., species that occurred in two of the three habitats, and expected them to have similar fatty acid profiles and contents irrespective of the habitat.

\section{Results and Discussion}

\subsection{Growth Rates}

The growth rate $(\mu)$ is one of the most important parameters when estimating the feasibility of commercial algal cultivation [33]. The maximal growth rates of both diatoms $\left(0.07-0.46\right.$ divisions day $\left.^{-1}\right)$ and dinoflagellates $\left(0.08-0.33\right.$ divisions day $\left.^{-1}\right)$ varied between strains, but could not be associated with the habitat, i.e., marine, brackish or freshwater (Table 1). The observed growth rates were in general in line with the ones reported for microalgae, e.g., for the diatoms Chaetoceros brevis and Thalassiosira weissflogii [34], the eustigmatophyte Nannochloropsis, and several other marine and freshwater species that all are considered as potential sources of commercial $\omega-3$ PUFA production $[35,36]$. Trying to optimize the growth rates (i.e., adjusting the culture medium composition as well as salinity, temperature, and light conditions) was not within the scope of the present study, but, based on the observed growth in the current conditions, the marine strain of Skeletonema marinoi especially showed potential for commercial applications (Table 1). 
Table 1. The investigated marine, brackish and freshwater diatom and dinoflagellate strains and their growth conditions (medium, temperature, and light intensity) as well as their potential toxicity based on literature [37-42], the cell numbers in the cultures in the late exponential growth phase, and maximal growth rates (calculated for the exponential growth phase using Equation 1). Strain numbers refer to Figures 1 and 2.

\begin{tabular}{|c|c|c|c|c|c|c|c|c|c|c|}
\hline Habitat & Number & Diatoms & Origin of Strain & Collection Site, Isolated by (Year) & Medium & $\begin{array}{c}\text { Temperature } \\
\left({ }^{\circ} \mathrm{C}\right)\end{array}$ & $\begin{array}{l}\text { Light ( } \mu \text { mol } \\
\text { quanta s s-1 } \\
\left.\mathrm{m}^{-2}\right)\end{array}$ & $\begin{array}{c}\text { Potentially } \\
\text { Toxic } \\
\text { (Yes/No) }\end{array}$ & $\begin{array}{l}\text { Cells (cells } \\
\mathrm{mL}^{-1} \text { ) }\end{array}$ & $\begin{array}{c}\mu \text { Max } \\
\begin{array}{c}\text { (divisions } \\
\text { day }^{-1} \text { ) }\end{array}\end{array}$ \\
\hline \multirow{3}{*}{ Marine } & M1 & Pseudo-nitzschia pungens CCAP & СCAP & LY1, Argyll, Scotland, UK; Garvetto (2015) & $\mathrm{F} / 2+\mathrm{Si}, 30 \mathrm{psu}$ & 16 & 115 & yes & $5.5 \times 10^{4}$ & 0.18 \\
\hline & M2 & $\begin{array}{l}1066 / 144 \\
\text { Skeletonema marinoi K-0669 }\end{array}$ & NORCCA (SCCAP) & Hvidøre, Øresund (The Sound), Denmark; N.H. Larsen (2004) & $\mathrm{F} / 2+\mathrm{Si}, 30 \mathrm{psu}$ & 4 & 115 & no & $1.3 \times 10^{6}$ & 0.46 \\
\hline & М3 & $\begin{array}{c}\text { Thalassiosira nordenskioldii CCAP } \\
1085 / 31\end{array}$ & CCAP & Arctic waters, West Greenland Shelf; Fragoso (2013) & $\mathrm{F} / 2+\mathrm{Si}, 30 \mathrm{psu}$ & 4 & 115 & no & $3.7 \times 10^{4}$ & 0.22 \\
\hline \multirow{4}{*}{ Brackish } & B1 & Diatoma tenuis DTTV B5 & FINMARI CC & Tvärminne Storfärrden, Baltic Sea; A. Kremp (2008) & $\mathrm{F} / 2+\mathrm{Si}, 6 \mathrm{psu}$ & 4 & 115 & no & $1.0 \times 10^{5}$ & 0.33 \\
\hline & B2 & Melosira arctica MATV-1402 & FINMARI CC & $\begin{array}{l}\text { Längden, Tvärminne, Baltic Sea; J. Oja (2014) } \\
\text { (20) }\end{array}$ & $\mathrm{F} / 2+\mathrm{Si}, 6 \mathrm{psu}$ & 4 & 115 & no & $2.1 \times 10^{5}$ & 0.32 \\
\hline & $\begin{array}{l}\text { D2 } \\
\text { B3 }\end{array}$ & Skeletonema marinoi Skeletonema & FINMARI CC & Tvärminne Storfärden, Baltic Sea; K. Spilling (2006) & $\begin{array}{l}\mathrm{F} / \mathrm{LSH}, \mathrm{opsu} \\
\mathrm{F} / 2+\mathrm{Si}, 6 \mathrm{psu}\end{array}$ & 4 & 115 & no & $1.1 \times 10^{6}$ & 0.25 \\
\hline & B4 & Thalassiosira baltica TBLL7-1301 & FINMARI CC & LL7, Gulf of Finland, Baltic Sea; A. Kremp (2013) & $\mathrm{F} / 2+\mathrm{Si}, 6 \mathrm{psu}$ & 4 & 115 & no & $7.2 \times 10^{4}$ & 0.19 \\
\hline \multirow{3}{*}{ Freshwater } & F1 & Diatoma tenuis CPCC 62 & CPCC & Lake Ontario, Canada; C. Ewing (1984) & MWC & 18 & 70 & no & $2.6 \times 10^{4}$ & 0.22 \\
\hline & $\mathrm{F} 2$ & Nitzschia sp. FD397 & UTEX & Minnesota, USA; D. Czarnecki (1998) & MWC & 18 & 70 & no & $1.5 \times 10^{5}$ & 0.20 \\
\hline & F3 & $\begin{array}{l}\text { Stephanodiscus hantzschii CPCC } 267 \\
\text { (CCAP 1079/4) }\end{array}$ & СPCC & Esthwaite Water, Cumbria, England, UK; Jaworski (1983) & MWC & 18 & 70 & no & $6.9 \times 10^{5}$ & 0.07 \\
\hline & & Dinoflagellates & & & & & & & & \\
\hline Marine & M4 & Apocalathium malmogiense $\mathrm{K}-0399$ & NORCCA (SCCAP) & Igloolik Island, Canada; N. Daugbjerg (1989) & $\mathrm{F} / 2-\mathrm{Si}, 30 \mathrm{psu}$ & 4 & 115 & no & $1.3 \times 10^{4}$ & 0.12 \\
\hline \multirow{4}{*}{ Brackish } & B5 & Alexandrium ostenfeldii AOF-0926 & FINMARICC & Föglö, Åland Islands, Baltic Sea; A. Kremp (2009 & $\mathrm{F} / 2-\mathrm{Si}, 6 \mathrm{psu}$ & 16 & 115 & yes & $3.9 \times 10^{3}$ & 0.08 \\
\hline & B6 & Apocalathium malmogiense SHTV-5 & FINMARI CC & Tvärminne Storfä̈rden, Baltic Sea; A. Kremp (2002) & $\mathrm{F} / 2-\mathrm{Si}, 6 \mathrm{psu}$ & 4 & 115 & no & $2.6 \times 10^{4}$ & 0.14 \\
\hline & B7 & Heterocapsa triquetra HTF 1002 & FINMARI CC & Föglö, Åland Islands, Baltic Sea; P. Hakanen (2010) & $\mathrm{F} / 2-\mathrm{Si}, 6 \mathrm{psu}$ & 16 & 115 & no & $3.0 \times 10^{4}$ & 0.33 \\
\hline & B8 & Karlodinium veneficum KVDAN 22 & FINMARI CC & Danskog, Raseborg, Baltic Sea; M. Parrow (2013) & $\mathrm{F} / 2-\mathrm{Si}, 6 \mathrm{psu}$ & 16 & 115 & yes & $5.0 \times 10^{4}$ & 0.16 \\
\hline \multirow{2}{*}{ Freshwater } & F4 & Gymnodinium fuscum K-1836 & NORCCA (SCCAI & Lake Fiolen, Sweden; G. Hansen (2012) & MWC & 18 & 70 & no & $1.3 \times 10^{6}$ & nd \\
\hline & F5 & Peridinium cinctum K-1721 & NORCCA (SCCAP) & Freshwater rockpool, Tvärminne, Finland; G. Hansen (2011) & MWC & 18 & 70 & no & $2.6 \times 10^{4}$ & nd \\
\hline
\end{tabular}

Abbreviations: CCAP = Culture Collection of Algae and Protozoa; FINMARI CC = FINMARI Culture Collection/SYKE Marine Research Centre and Tvärminne Zoological Station;

NORCCA = Norwegian Culture Collection of Algae; SCCAP = (the former) Scandinavian Culture Collection for Algae \& Protozoa; UTEX = UTEX Culture Collection of Algae at the

University of Texas at Austin. nd $=$ not determined. 


\subsection{Phylogeny and Habitat Explaining the Proportional Fatty Acid Profiles and Contents of Diatoms and Dinoflagellates}

Fatty acid profiles of diatoms and dinoflagellates varied by habitat, but also by strain (Figure 1). Principal component analysis (PCA) separated the diatoms and the dinoflagellates into their own groups in spite of the habitat (Figure 2A). In fact, the taxonomy explained $46 \%$ and habitat $13 \%$ of the variation in fatty acid profiles (PERMANOVA, Table 2). However, there was less dispersion among diatoms than among dinoflagellates in the PCA (Figure 2A) indicating stronger similarities in the fatty acid profiles of the studied diatoms than those of the dinoflagellates. Furthermore, the PERMANOVA also showed differences in fatty acid profiles of diatoms and dinoflagellates between the habitats. Habitat explained 39\% (PERMANOVA, $\mathrm{F}_{(2,20)}=5.82, p=0.001$ ) and 59\% (PERMANOVA, $\mathrm{F}_{(2,13)}=7.76$, $p=0.001$ ) of the variation in the proportional fatty acid profiles of diatoms and dinoflagellates, respectively. Pairwise PERMANOVA showed differences between brackish and marine $(\mathrm{t}=2.20$, $p=0.003)$ and freshwater $(t=3.14, p=0.001)$ diatoms, whereas the fatty acid profiles of the marine and the freshwater diatoms did not differ $(\mathrm{t}=1.44, p=0.151)$. SIMPER analysis showed that these differences were related to a higher proportion of 16:1 $\omega 7 \mathrm{c}$ (explained 39-49\% of differences) and 14:0 (explained $12-23 \%$ of differences) in brackish diatoms than in the marine or freshwater strains. In contrast to that, the brackish diatoms had a smaller proportion of EPA (explained 12-20\% of differences) than the marine or the freshwater strains. The fatty acid profiles of brackish and freshwater dinoflagellates differed in oleic acid (18:1cis-9; explained 59\% of differences) and in OPA (octadecapentaenoic acid; 18:5 $\omega-3$ ) (explained 12\% of differences): the freshwater strains had more oleic acid and less OPA than the brackish strains. The comparison between the brackish and the freshwater or the marine strains could not be done since we succeeded to culture only one marine dinoflagellate. Galloway and Winder [16] has reported that the taxonomic group accounts for 3-4 times more variation in the fatty acid profiles than the environment; however, our study suggests that some taxonomic groups may not fit into this, and thus the habitat can explain more of the variation than suggested earlier.

Table 2. Permutational multivariate analysis of variance (PERMANOVA) results for comparisons of fatty acid concentration by phytoplankton group, i.e., taxonomy (Ph), habitat (Ha), and their interactions. SS sum of squares, MS mean squares, $\mathrm{P}($ perm) significance, $\mathrm{P}(\mathrm{MC})$ significance after Montecarlo correction.

\begin{tabular}{|c|c|c|c|c|c|c|}
\hline Source & df & SS & MS & Pseudo-F & $P($ perm $)$ & P (MC) \\
\hline \multicolumn{7}{|c|}{ Profile Model } \\
\hline $\mathrm{Ph}$ & 1 & 13771 & 13771 & 53.987 & 0.001 & 0.001 \\
\hline На & 2 & 3846 & 1923 & 7.5405 & 0.001 & 0.001 \\
\hline $\mathrm{PhxHa}$ & 2 & 3310 & 1655 & 6.4893 & 0.001 & 0.001 \\
\hline Res & 29 & 7397 & 255 & & & \\
\hline Total & 34 & 29649 & & & & \\
\hline \multicolumn{7}{|c|}{ Content Model } \\
\hline $\mathrm{Ph}$ & 1 & 6260 & 6260 & 30.196 & 0.001 & 0.001 \\
\hline $\mathrm{Ha}$ & 2 & 7956 & 3978 & 19.186 & 0.001 & 0.001 \\
\hline $\mathrm{PhxHa}$ & 2 & 5159 & 2579 & 12.442 & 0.001 & 0.001 \\
\hline Res & 29 & 6012 & 207 & & & \\
\hline Total & 34 & 26083 & & & & \\
\hline
\end{tabular}

Our PCA analysis on the fatty acid contents ( $\mu \mathrm{g}$ FA mg in DW) of diatoms and dinoflagellates separated the strains into taxonomic groups by the component 2 , whereas the component 1 separated the freshwater strains from the marine and the brackish (Figure 2B). Additionally, the freshwater diatoms were more positively and freshwater dinoflagellates more negatively related to component 1 than the brackish or marine strains. When all data were considered, the habitat explained $31 \%$ of the observed variation, whereas the taxonomic group explained only $24 \%$ (Table 2). More specifically, 
within diatoms the habitat explained $47 \%$ (PERMANOVA, $\mathrm{F}_{(2,20)}=7.92, p=0.001$ ) of the variance in the fatty acid concentrations and in dinoflagellates $82 \%$ (PERMANOVA, $\mathrm{F}_{(2,13)}=25.0, p=0.001$ ). The pairwise PERMANOVA showed difference $(\mathrm{t}=2.5-3.1, p=0.003-0.0011)$ between all habitats in diatoms and between brackish and freshwater dinoflagellates $(t=6.6, p=0.001)$. The freshwater diatoms had higher EPA and 16:1 $\omega 7$ content than the brackish or marine strains (SIMPER, EPA and $16: 1 \omega 7$ explained $22 \%$ and $19 \%$ of dissimilarity, respectively), whereas the brackish strains had more $16: 1 \omega 7,16: 0$ and 14:0 (explaining together $73 \%$ of dissimilarity) than the marine strains. This result shows that, even though the proportional fatty acid profiles are phylogenetically ordered, the actual fatty acid contents may vary depending on habitat.
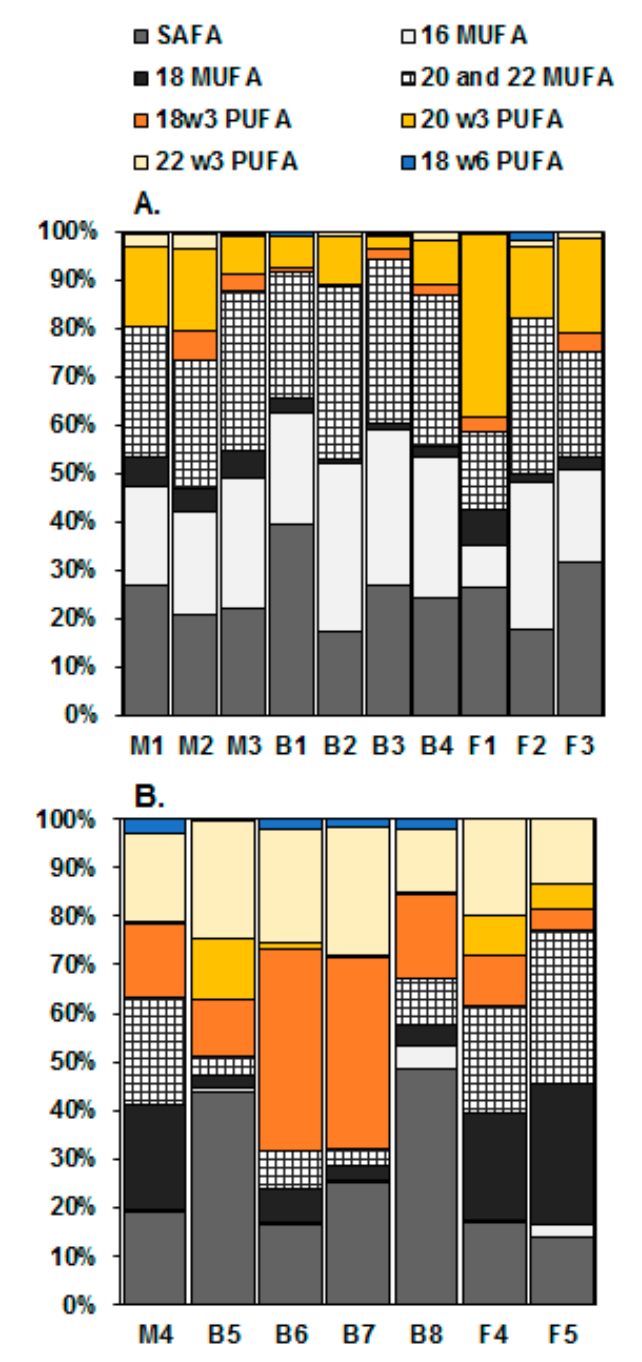

Figure 1. The fatty acid profiles of the studied diatoms (A) and dinoflagellates (B) as \% of the total fatty acids. $18 \omega-3$ is the sum of alpha-linolenic acid (ALA), stearidonic acid (SDA) and octadecapentaenoic acid (OPA), $20 \omega-3$ is eicosapentaenoic acid (EPA), $22 \omega-3$ is docosahexaenoic acid (DHA), $18 \omega-6$ is the sum of linoleic acid (LA) and gamma-linolenic acid (GLA), MUFA is mono-unsaturated fatty acids (16 MUFA, 18 MUFA and other MUFA) and SAFA is saturated fatty acids. For numbering of strains, see Table 1. 

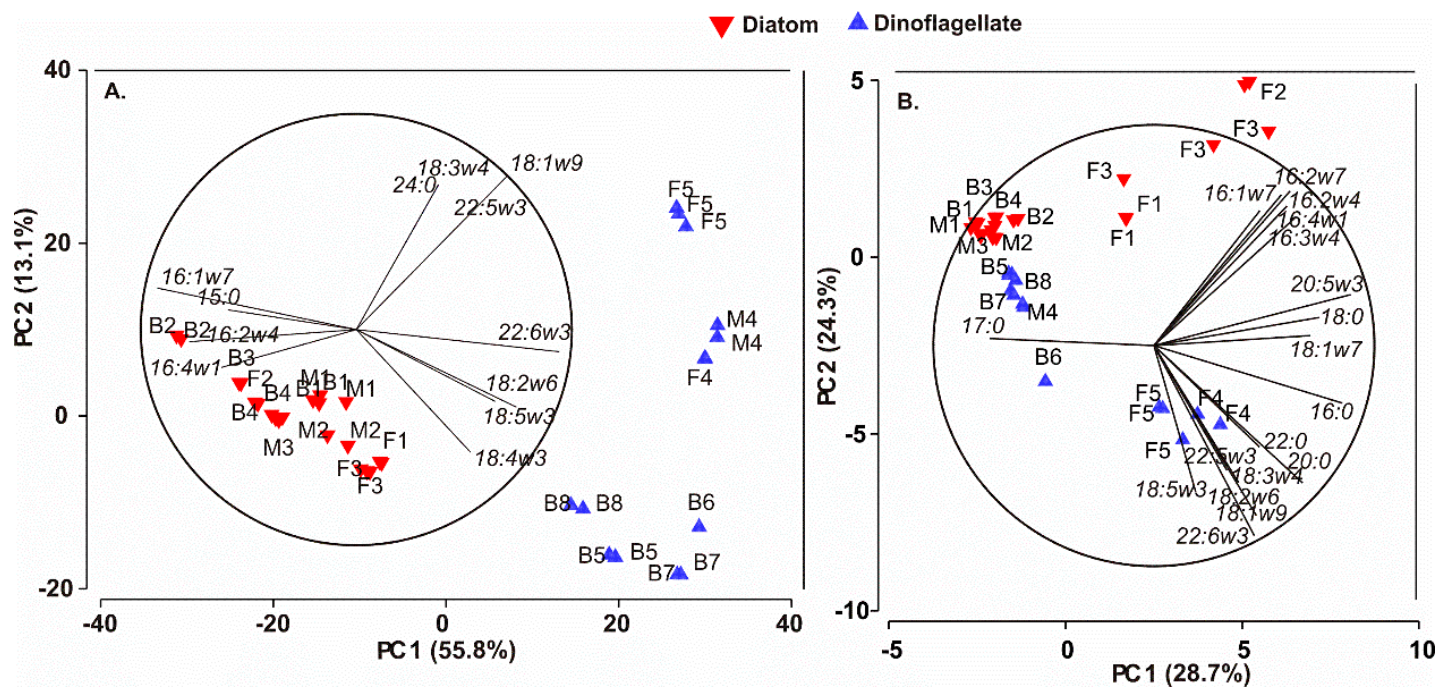

Figure 2. The principal component analysis (PCA) plot of the studied marine, brackish and freshwater diatoms (red inverted triangles) and dinoflagellates (blue triangles) based on (A) their fatty acid profiles (as \% of the total fatty acids), and (B) based on their fatty acid concentrations ( $\mu$ g FA in mg DW). The marine strains are denoted with the letter $\mathrm{M}$, brackish with B and freshwater with F; for numbering of strains, see Table 1. The strain pairs, i.e., species that occurred in two of the three habitats, are M2-B3, B1-F1, and M4-B6.

\subsection{The Total Fatty Acid Contents of Diatoms and Dinoflagellates}

In addition to fatty acid profile and content of individual fatty acids, we compared total fatty acid content of diatoms and dinoflagellates. In the diatoms, the total sum of all fatty acids was highest in the freshwater strains and lowest in the marine strains (ANOVA $p<0.001$; Table 3). The total fatty acid contents of the marine diatoms were actually surprisingly low (2.6-11.4 $\mu \mathrm{g}$ FA in mg DW) when compared to the concentrations reported earlier for microalgae (i.e., 12-40 $\mu \mathrm{g}$ FA in mg DW [43]). In the brackish diatom strains the total fatty acids (14.4-50.0 $\mu \mathrm{g}$ FA in $\mathrm{mg}$ DW) were close to the earlier reported [43], but in the freshwater strains substantially higher (53.8-133.9 $\mu \mathrm{g}$ FA in mg DW; Table 3). The nutritional value of diatoms for zooplankton has been shown to differ greatly at different stages of growth $[7,44]$. However, to take into account this variation, the microalgae were grown to the late exponential growth phase in this study. Thus, different growth phases should not be the cause for the obtained differences in the total fatty acid contents of the diatoms. The total fatty acid content did not differ between the two $S$. marinoi strains from the marine and brackish habitats, but was significantly higher in the freshwater than in the brackish Diatoma tenuis (ANOVA $p<0.001$; Table 4). 
Table 3. Habitat-specific diatom and dinoflagellate averages of total fatty acids, $\omega-3$, ALA, SDA, OPA, EPA, DHA, $\omega-6$, LA, GLA, ARA, DPA and $\omega-6: 3$ ratios. Standard deviations are given in the parenthesis.

\begin{tabular}{|c|c|c|c|c|c|c|c|c|c|c|c|c|c|c|}
\hline Taxa & Habitat & $\begin{array}{c}\text { Total FA } \\
(\mu \mathrm{g} \mathrm{FA} \mathrm{mg} \\
\left.\text { DW }^{-1}\right)\end{array}$ & $\begin{array}{c}\omega-3 \\
(\mu \mathrm{g} \mathrm{FA} \\
\mathrm{mg} \\
\left.D W^{-1}\right)\end{array}$ & $\begin{array}{c}\text { ALA } \\
(\mu \mathrm{g} \mathrm{FA} \\
\text { mg } \\
\left.\mathrm{DW}^{-1}\right)\end{array}$ & $\begin{array}{c}\text { SDA } \\
(\mu \mathrm{g} \mathrm{FA} \\
\mathrm{mg} \\
\left.\mathrm{DW}^{-1}\right)\end{array}$ & $\begin{array}{c}\text { OPA } \\
(\mu \mathrm{g} \mathrm{FA} \\
\mathrm{mg} \\
\left.\mathrm{DW}^{-1}\right)\end{array}$ & $\begin{array}{c}\text { EPA } \\
(\mu \mathrm{g} \mathrm{FA} \\
\mathrm{mg} \\
\left.\mathrm{DW}^{-1}\right)\end{array}$ & $\begin{array}{c}\text { DHA } \\
(\mu \mathrm{g} \mathrm{FA} \\
\text { mg } \\
\left.\mathrm{DW}^{-1}\right)\end{array}$ & $\begin{array}{c}\omega-6 \\
(\mu \mathrm{g} \mathrm{FA} \\
\mathrm{mg} \\
\left.\mathrm{DW}^{-1}\right)\end{array}$ & $\begin{array}{c}\text { LA } \\
(\mu \mathrm{g} \mathrm{FA} \\
\mathrm{mg} \\
\left.\mathrm{DW}^{-1}\right)\end{array}$ & $\begin{array}{c}\text { GLA } \\
\left(\begin{array}{c}\mu \mathrm{gFA} m g \\
\left.\mathrm{DW}^{-1}\right)\end{array}\right.\end{array}$ & $\begin{array}{c}\text { ARA } \\
\underset{(\mu \mathrm{g} \mathrm{FA} \mathrm{mg}}{\left.\mathrm{DW}^{-1}\right)}\end{array}$ & $\begin{array}{c}\text { DPA } \\
(\mu \mathrm{g} \mathrm{FA} \\
\text { mg } \\
\left.\mathrm{DW}^{-1}\right)\end{array}$ & $\begin{array}{l}\omega-6: 3 \\
- \text { ratio }\end{array}$ \\
\hline & Marine & $7.6(4.5)$ & $1.7(1.2)$ & $0.1(0.1)$ & $0.3(0.3)$ & $0.01(0.01)$ & $1.1(0.7)$ & $0.2(0.1)$ & $0.1(0.04)$ & $0.1(0.04)$ & $\begin{array}{c}0.007 \\
(0.0007)\end{array}$ & $0.003(0.003)$ & - & $1: 25$ \\
\hline Diatoms & $\begin{array}{l}\text { Brackish } \\
\text { Freshwater }\end{array}$ & $\begin{array}{c}26.3(15.2) \\
88.9(36.5)^{*}\end{array}$ & $\begin{array}{c}3.7(3.2) \\
21.1(6.2) *\end{array}$ & $\begin{array}{l}0.02(0.01) \\
0.2(0.1)^{*}\end{array}$ & $\begin{array}{l}0.4(0.2) \\
1.5(1.2)\end{array}$ & $\begin{array}{c}0.01(0.01) \\
-\end{array}$ & $\begin{array}{c}2.9(2.7) \\
17.4(5.2) *\end{array}$ & $\begin{array}{c}0.3(0.2) \\
1.2(0.9)^{*}\end{array}$ & $\begin{array}{l}0.3(0.2) \\
0.6(0.3)\end{array}$ & $\begin{array}{l}0.2(0.1) \\
0.5(0.3)\end{array}$ & $\begin{array}{c}0.04(0.02) * \\
-\end{array}$ & $\begin{array}{l}0.1(0.1) \\
0.9(0.8)\end{array}$ & $\begin{array}{c}- \\
0.1(0.1)\end{array}$ & $\begin{array}{l}1: 14 \\
1: 36\end{array}$ \\
\hline Dinoflagellates & $\begin{array}{l}\text { Marine } \\
\text { Brackish } \\
\text { Freshwater }\end{array}$ & $\begin{array}{c}44.3(1.1)^{\dagger} \\
37.8(20.3) \\
140.4(7.0)^{*}\end{array}$ & $\begin{array}{l}13.7(0.8)^{\dagger} \\
15.1(10.4) \\
45.8(5.3)^{*}\end{array}$ & $\begin{array}{c}0.2(0.01)^{\dagger} \\
0.4(0.3) \\
0.1(0.1)\end{array}$ & $\begin{array}{c}2.0(0.1)^{\dagger} \\
4.5(4.3) \\
3.4(2.9)\end{array}$ & $\begin{array}{c}6.3(0.2)^{\dagger} \\
7.0(7.0) \\
8.7(8.0)\end{array}$ & $\begin{array}{c}0.3(0.1)^{\dagger} \\
1.1(1.0) \\
11.6(2.1)^{*}\end{array}$ & $\begin{array}{c}10.4(0.6)^{\dagger} \\
8.6(5.7) \\
29.7(5.3)^{*}\end{array}$ & $\begin{array}{c}1.7(0.1)^{\dagger} \\
1.0(0.6) \\
1.4(1.0)\end{array}$ & $\begin{array}{c}1.6(0.04)^{\dagger} \\
0.9(0.5) \\
1.4(1.0)\end{array}$ & $\begin{array}{l}0.12(0.01)^{+} \\
0.04(0.002) \\
0.03(0.005)\end{array}$ & $\begin{array}{c}0.3(0.005)^{\dagger} \\
0.3(0.3) \\
0.02(0.02)\end{array}$ & $\begin{array}{l}- \\
- \\
-\end{array}$ & $\begin{array}{l}1: 8^{+} \\
1: 16 \\
1: 32\end{array}$ \\
\hline
\end{tabular}


Table 4. Strain-specific averages of total fatty acids, $\omega-3$, ALA, SDA, OPA, EPA, DHA, $\omega-6$, LA, GLA, ARA, DPA and $\omega-6: 3$ ratios of the studied strains from the three studied habitats, i.e., marine, brackish and freshwater environments. Standard deviations are given in the parenthesis.

\begin{tabular}{|c|c|c|c|c|c|c|c|c|c|c|c|c|c|c|}
\hline Habitat & Diatoms & $\begin{array}{c}\text { Total FA } \\
(\mu \mathrm{gAA} \mathrm{mg} \\
\left.\mathrm{DW}^{-1}\right)\end{array}$ & $\begin{array}{c}\omega-3 \\
(\mu \mathrm{g} \mathrm{FA} \\
\mathrm{mg} \\
\left.\mathrm{DW}^{-1}\right)\end{array}$ & $\begin{array}{c}\text { ALA } \\
\left(\begin{array}{c}\mu \mathrm{gA} \text { FAg } \\
\left.\text { DW }^{-1}\right)\end{array}\right.\end{array}$ & $\begin{array}{c}\text { SDA } \\
(\mu g \text { FA } \\
\text { mg } \\
\left.\mathrm{DW}^{-1}\right)\end{array}$ & $\begin{array}{c}\text { OPA } \\
\underset{(\mu g \text { FA mg }}{\left.\text { DW }^{-1}\right)}\end{array}$ & $\begin{array}{c}\text { EPA } \\
(\mu \mathrm{g} \mathrm{FA} \\
\mathrm{mg} \\
\left.\mathrm{DW}^{-1}\right)\end{array}$ & $\begin{array}{c}\text { DHA } \\
\left(\begin{array}{c}\text { g FA mg } \\
\left.\text { DW }^{-1}\right)\end{array}\right.\end{array}$ & $\begin{array}{c}\omega-6 \\
(\mu g \text { FA } \\
\text { mg } \\
\left.\mathrm{DW}^{-1}\right)\end{array}$ & $\begin{array}{c}\mathrm{LA} \\
(\mu \mathrm{g} \mathrm{FA} \\
\mathrm{mg} \\
\left.\mathrm{DW}^{-1}\right)\end{array}$ & $\begin{array}{c}\text { GLA } \\
\underset{(\mu \mathrm{g} \mathrm{FA} \mathrm{mg}}{\left.\mathrm{DW}^{-1}\right)}\end{array}$ & $\begin{array}{c}\text { ARA } \\
\underset{(\mu g \text { FA mg }}{\left.\text { DW }^{-1}\right)}\end{array}$ & $\begin{array}{c}\text { DPA } \\
(\mu \mathrm{g} \mathrm{FA} \\
\mathrm{mg} \\
\left.\mathrm{DW}^{-1}\right)\end{array}$ & $\begin{array}{l}\omega-6: 3 \\
- \text { ratio }\end{array}$ \\
\hline \multirow{3}{*}{ Marine } & $\begin{array}{l}P_{\text {seudo-nitzschia pungens CCAP }} \\
1061 / 44\end{array}$ & $2.6(1.2)$ & $0.6(0.2)$ & $0.0003(0.001)$ & - & - & $0.5(0.02)$ & $0.08(0.03)$ & $0.03(0.03)$ & $0.03(0.03)$ & $0.01(0.001)$ & $0.02(0.01)$ & - & $1: 24$ \\
\hline & Skeletonema marinoi K-0669 & $11.4(3.4)$ & $2.9(0.6)$ & $0.03(0.005)$ & $0.7(0.2)$ & $0.02(0.02)$ & $1.9(0.4)$ & $0.3(0.02)$ & $0.1(0.01)$ & $0.1(0.01)$ & $0.01(0.001)$ & - & - & 1:27 \\
\hline & $\begin{array}{l}\text { Thalassiosira nordenskioldii CCAP } \\
1085 / 31\end{array}$ & $8.8(2.5)$ & $1.4(0.9)$ & $0.2(0.1)$ & $0.2(0.1)$ & - & $1.0(0.7)$ & $0.1(0.05)$ & $0.1(0.02)$ & $0.1(0.1)$ & - & - & - & 1:24 \\
\hline \multirow{4}{*}{ Brackish } & Diatoma tenuis DTTV B5 & $16.8(2.1)$ & 1.2 & 0. & $0.2(0.1)$ & - & $1.3(\mathrm{C}$ & $0.02(0.04)$ & 0.3( & $0.2(0.02)$ & $0.05(0.01)$ & $0.01(0.002)$ & - & 1:5 \\
\hline & Melosira arctica MATV-1402 & $50.0(3$ & $8.5(0.4)^{*}$ & $0.03(0$ & $0.3(0.01)$ & $0.02(0.002)$ & $7.0(0.3)^{*}$ & $0.5(0.002) *$ & $0.5(0.01)$ & $0.3(0.006)$ & $0.09(0.002)$ & $0.4(0.0$ & - & 1:18 \\
\hline & Skeletonema marinoi Skeletonema & 14.4( & $1.0(0.1)$ & $0.02(0$. & $0.4(0.002)$ & $0.02(0.05)$ & $0.5(0.1)$ & $0.1(0.05)$ & $0.1(0.002)$ & $0.1(0.01)$ & $0.01(0.003)$ & 0.007 ( & - & $1: 9$ \\
\hline & Thalassiosira baltica TBLL7-1301 & $24.1(0.7)$ & $3.8(0.1)$ & $0.4(0.1)$ & $0.6(0.03)$ & - & $2.7(0.1)$ & $0.4(0.01)$ & $0.1(0.01)$ & $0.1(0.01)$ & $0.02(0.004)$ & $0.01(0.001)$ & - & $1: 29$ \\
\hline \multirow{4}{*}{ Freshwater } & Diatoma tenuis СРСС 62 & $53.8(0.4) *$ & $20.7(0.2) *$ & $0.3(0.01)$ & $1.2(0.02)$ & - & $18.9(0.3)^{*}$ & $0.2(0.01)$ & $0.9(0.04) *$ & $0.9(0.02)^{*}$ & - & $0.2(0.01)$ & - & $1: 23$ \\
\hline & Nitzschia sp. FD397 & $133.9(2.5)^{*}$ & $28.8(0.2)^{*}$ & $0.03(0.01)$ & $0.3(0.01)$ & - & $23.1(0.2)^{*}$ & $2.4(0.03)^{*}$ & $0.3(0.03)$ & $0.3(0.01)$ & - & $3.0(0.4)^{*}$ & - & 1:95 \\
\hline & $\begin{array}{l}\text { Stephanodiscus hantzschii CPCC } 267 \\
\text { (CCAP 1079/4) }\end{array}$ & $82.3(26.0) *$ & $16.3(4.8)^{*}$ & $0.2(0.1)$ & $2.6(1.0)$ & - & $12.6(3.5)^{*}$ & $1.0(0.2)^{*}$ & $0.6(0.2)$ & $0.4(0.1)$ & - & $0.03(0.01)$ & $0.1(0.03)^{*}$ & $1: 29$ \\
\hline & Dinoflagellates & & & & & & & & & & & & & \\
\hline Marine & Apocalathium malmogiense K-0399 & $44.3(1.1)$ & $13.4(0.8)$ & $0.2(0.1)$ & $2.0(0.1)$ & $6.2(0.3)$ & $0.3(0.1)$ & $10.4(0.6)$ & $1.7(0.1)$ & $1.6(0.01)$ & $0.1(0.01)$ & $0.3(0.01)$ & - & $1: 8$ \\
\hline \multirow{4}{*}{ Brackish } & Alexandrium ostenfeldii AOF-0926 & $27.1(0.7)$ & $13.4(0.6)$ & $0.1(0.01)$ & $3.0(0.1)$ & $1.1(0.003)$ & $3.4(0.02)$ & $6.6(0.08)$ & $0.9(0.04)$ & $0.8(0.03)$ & $0.04(0.004)$ & $0.03(0.0003)$ & - & $1: 14$ \\
\hline & Apo & & 36 & 0. & & 23 & 0.8 & & 2. & 1. & 1.1 & 0.2 & - & 1:16 \\
\hline & Heterocapsa triquetra HTF 1002 & & $15.5(1.2)$ & & & $7.3(0.6)$ & & 9.0( & $0.5(0.01)$ & $0.5(0.001)$ & 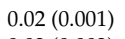 & $0.3(0.01)$ & - & $1: 29$ \\
\hline & Karlodinium veneficum KVDAN 22 & $30.7(3.0)$ & $5.9(1.1)$ & $0.3(0.04)$ & $0.9(0.1)$ & $4.7(0.8)$ & $0.2(0.01)$ & $4.3(0.8)$ & $0.7(0.1)$ & $0.7(0.02)$ & $0.02(0.002)$ & $0.2(0.01)$ & - & 1:8 \\
\hline \multirow{2}{*}{ Freshwater } & Gymnodinium fu & )$^{*}$ & $48.1(3.8)^{*}$ & $0.02(0$ & $0.2(0.01)$ & $17.5(0.1)^{*}$ & $13.7(0.2)^{*}$ & $34.1(1$ & $2.6(0.1)^{*}$ & $2.2(0$ & & $0.05(0.004)$ & - & 1:19 \\
\hline & Peridinium cinctum K-1721 & $3.0(8.1)^{*}$ & $44.3(6.9)^{*}$ & $0.1(0.01)^{*}$ & $5.6(0.5)^{*}$ & $2.9(0.4)$ & $10.2(1.3) *$ & $26.8(4.8)^{*}$ & $0.7(0.05)$ & $0.7(0.01) *$ & $0.06(0.01)$ & & . & $1: 68$ \\
\hline
\end{tabular}

Abbreaviations: total FA (total fatty acids), $\omega-3$ (total $\omega-3$ fatty acids, ALA + SDA (alpha-linolenic acid, 18:3 $\omega-3$ and stearidonic acid, 18:4: $\omega-3$ ), OPA (octadecapentaenoic acid; 18:5 $\omega-3$ ),

EPA (eicosapentaenoic acid, 20:5w-3), DHA (docosahexaenoic acid, 22:6w-3), $\omega-6$ (total $\omega$-6 fatty acids). LA (linoleic acid, 18:2 $\omega-6$ ), GLA (gamma-linolenic acid; 18:3 $\omega-6$ ), ARA

(arachidonic acid, 20:4w-6), DPA (docosapentaenoic acid, 22:5 $\omega-6$ ). The statistical testing was done with ANOVA, ${ }^{*}=p<0.01 . \dagger=$ the results of the marine $A$. malmogiense could not be

statistically tested due to a low number of replicates from this strain. 
A trend was observed in the total fatty acids of the dinoflagellates as well, but the order was freshwater $>$ marine $>$ brackish (Table 3 ). The total fatty acid concentrations in the marine (44.3 $\mu \mathrm{g}$ FA in mg DW) and the brackish dinoflagellates (27.1-83.3 $\mu \mathrm{g}$ FA in mg DW) were comparable to the earlier studies on microalgae (12-40 $\mu \mathrm{g}$ FA in mg DW [43]). As in the diatoms, also in the dinoflagellates, the total fatty acid concentrations were highest in the freshwater strains (136.5-143.0 $\mu \mathrm{g}$ FA in mg DW; Table 4). Among the dinoflagellates, the marine strain of Apocalathium malmogiense had a lower total fatty acid content than the brackish $A$. malmogiense, but this could not be tested due to the lack of sample replicates of the latter (Table 4). The detailed fatty acid profiles and concentrations (in $\mu \mathrm{g}$ FA in mg DW) of the studied diatom and dinoflagellate strains are shown in the Supplementary Table S1.

\subsection{The w-3 and w-6 PUFA Contents and w-6:3-Ratios of Diatoms and Dinoflagellates}

The total sum of $\omega-3$ and $\omega-6$ PUFAs followed the trend of the total fatty acids. In general, the highest total $\omega-3$ PUFA concentrations were detected in the freshwater strains (ANOVA $p<0.001$; Table 3). The proportions of total $\omega-3$ fatty acids of total fatty acids in the diatoms (range 4-39\%) and in the dinoflagellates (range 19-49\%; Figure 1) were within the range reported for diatoms and microalgae in general (8-31\% [34-36]), but substantially lower than the values (range 64-81\%) reported for marine cryptophytes [27]. The $\omega-3$ profiles of the diatoms were more similar to each other than the profiles of the dinoflagellates from different habitats (Table 4). As expected, the diatoms had a higher EPA than DHA content and the dinoflagellates had a higher DHA than EPA content in all investigated habitats (Tables 3 and 4). Even though the share of EPA in the diatoms was 3-35\% of the total fatty acids, which is in accordance with the average proportions reported for marine and freshwater algae (10-25\% and 5-20\%, respectively) [2], the actual EPA concentrations were in general very low, and, in marine and brackish habitats, only slightly higher than in the dinoflagellates of the equivalent habitats. Among the diatoms, the highest total $\omega-3$ concentrations ( $28.8 \mu \mathrm{g}$ FA in mg DW) as well as EPA and DHA (23.1 and 2.4 $\mu \mathrm{g}$ FA in mg DW) concentrations were found in the freshwater Nitzschia sp. Marine cryptophytes are reported to be rich in $\omega-3$, especially in EPA and DHA, and the total $\omega-3$ and DHA values of the Nitzschia sp. were within the range detected from marine cryptophytes ( $\omega-3$ 25-59 $\mu \mathrm{g}$ FA in mg DW, DHA 1-6 $\mu \mathrm{g}$ FA in mg DW) and the EPA contents were even higher than in marine cryptophytes (6-13 $\mu \mathrm{g}$ FA in mg DW) [27]. In the dinoflagellates, the EPA content was up to ten times higher in the studied strains originating from freshwater habitats compared to those from marine and brackish habitats, and a similar trend was found also in DHA although the differences were smaller (Tables 3 and 4). Due to the differences in the total fatty acid concentrations, the proportions of DHA of total fatty acids were similar in the three habitats, i.e., $14-27 \%$, which are higher than the average proportions reported for marine and freshwater microalgae (5-10\% and $1-3 \%$, respectively) [2]. The highest DHA concentrations were detected in the freshwater dinoflagellate Gymnodinium fuscum (Table 4). These concentrations were ten times higher than those measured from marine cryptophytes [27].

The ALA and SDA contents were low both in the diatoms (1-6\% of total fatty acids) and in the dinoflagellates (1-13\% of total fatty acids), in all studied habitats (Figures 1 and 3, Table 3). These values are in accordance with the results of Twining and co-workers [2], who found that ALA is more commonly available in terrestrial (15-35\% of the total fatty acids of the primary producers) than in aquatic habitats ( $<15 \%$ of the total fatty acids of the primary producers) [2]. The marine diatom S. marinoi had a higher total $\omega-3$ and especially EPA content than the brackish S. marinoi, and the freshwater diatom $D$. tenuis had a higher total $\omega-3$, ALA, SDA and EPA content than the brackish D. tenuis (Table 4). Furthermore, the marine and brackish dinoflagellate A. malmogiense differed in $\omega-3$ fatty acids, the brackish strain having higher concentrations than the marine strain (Table 4). Our observations of the lower $\omega-3$ PUFA concentrations in the studied marine and brackish diatoms and dinoflagellates than in the freshwater strains indicate that there may be less $\omega-3$ PUFAs available in saline food webs than in freshwater food webs (Figure 3). All in all, the studied marine and brackish strains showed low potential for commercial EPA and DHA production. 

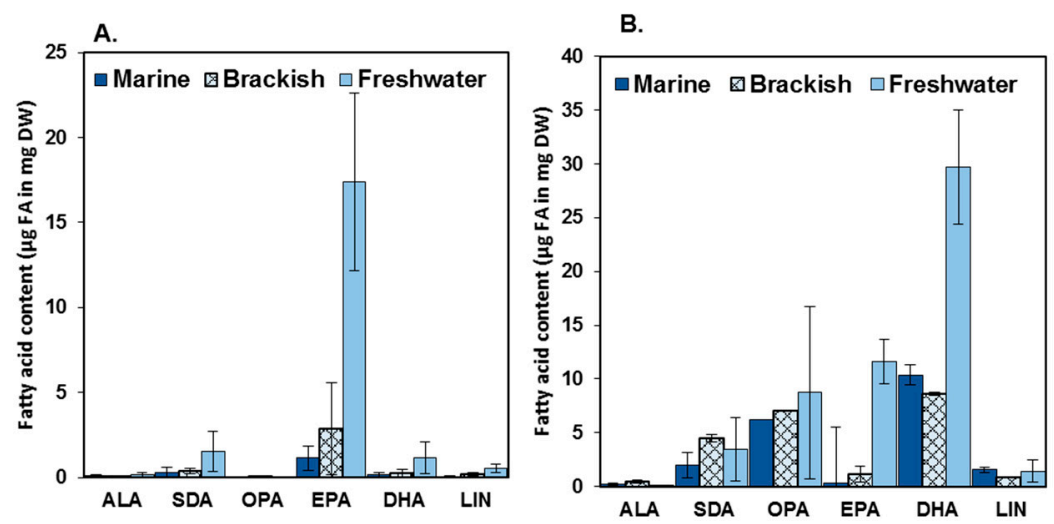

Figure 3. The concentrations ( $\mu \mathrm{g}$ FA in mg DW) of the most abundant $\omega-3$ and -6 fatty acids ALA (alpha-linolenic acid), SDA (stearidonic acid), OPA (octadecapentaenoic acid), EPA (eicosapentaenoic acid), DHA (docosahexaenoic acid) and LA (linoleic acid) of diatoms (A) and dinoflagellates (B) in the three studied habitats.

Diatoms and dinoflagellates are important bloom-formers in both marine and brackish habitats, and among them many toxin producing species occur [32,37-42]. Contrarily, in freshwater, toxic blooms of diatoms or dinoflagellates are rarely reported and toxic blooms are typically caused by cyanobacteria [38]. Of the studied species, the diatom Pseudo-nitzschia pungens and the dinoflagellates Alexandrium ostenfeldii and Karlodinium veneficum are known toxin producers [40-42]. The toxin production was not within the scope of this study, but we are also aware that of $\omega-3$ fatty acids, OPA excreted e.g., by some marine gymnodinioid dinoflagellate species, has been claimed to cause toxic effects e.g., in sea urchins [45], trout hepatocytes [46] and sheep red blood cells [47]. However, opposite results have also been published, and the current opinion is that OPA is not causing the toxicity [48]. It has also been reported that phytoplankton synthesize either OPA or EPA but rarely both [17]. Small amounts (1-7 $\mu \mathrm{g}$ FA in mg DW) of OPA were found in all studied marine and brackish dinoflagellates; however, the brackish A. malmogiense had a substantially higher OPA content $(23 \mu \mathrm{g}$ FA in mg DW). In diatoms, OPA was found only in minor amounts $(0.02 \mu \mathrm{g}$ FA in mg DW) and only in Melosira arctica and both S. marinoi strains (Table 4). Interestingly, the highest amount (17.5 $\mu \mathrm{g}$ FA in mg DW) of OPA was detected in the freshwater G. fuscum, which among dinoflagellates also had the highest EPA content (13.7 $\mu \mathrm{g}$ FA in mg DW) (Table 4).

The $\omega-6$ PUFA concentrations were more or less similar in all environments $(<2.6 \mu \mathrm{g}$ FA in $\mathrm{mg}$ DW; Tables 3 and 4), and the amounts were lower than those reported for e.g., cryptophytes and brown algae $[27,49]$. The $\omega-6$ concentrations were also very low compared to $\omega-3$ PUFAs, and constituted only $1-4 \%$ of the total fatty acids (Figure 1, Table 3 ). When comparing the species occurring in two habitats, higher total $\omega-6$ PUFA concentrations were found in the brackish than in the marine dinoflagellate $A$. malmogiense and in the freshwater than in the brackish diatom D. tenuis (ANOVA $p<0.001$ ). The marine and brackish S. marinoi did not differ in their total $\omega-6$ content (Table 4). Similarly to total $\omega-6$, the LA and ARA concentrations also did not vary between the habitats (Tables 3 and 4). However, the ARA concentration in the freshwater Nitzschia sp. was significantly higher than in any other studied strain (ANOVA $p<0.01$; Table 4). DPA was detected only in one strain, i.e., in the freshwater diatom Stephanodiscus hantzschii, which had minor DPA concentration (Table 4). Small amounts (0.01-0.1 $\mu \mathrm{g}$ FA in mg DW) of gamma-linolenic acid (GLA; 18:3w-6) were found in all studied strains except for the freshwater diatoms, the marine diatom Thalassiosira nordenskioldii and the freshwater dinoflagellate G. fuscum (Table 4). The $\omega-6: 3$-ratios varied a lot and were more or less similar in the diatoms and the dinoflagellates irrespective of the habitat (Table 4). The lowest $\omega-6: 3$-ratios were detected in the diatom Nitzschia sp. (1:95) and in the dinoflagellate Peridinium cinctum (1:68), but also, in all other strains, the $\omega-6: 3$-ratios were low and thus, in that sense, potentially suitable for products designed for balancing the $\omega-6: 3$-ratios of the Western diet [20]. 
We cannot explain the clear differences in the total fatty acid concentrations or in the specific $\omega-3$ fatty acids between the saline and freshwater strains. It is known that the growth conditions (nutrients, light and temperature) affect the fatty acid contents of microalgae. Regarding the nutrients, nitrogen limitation is often linked to high fatty acid production [17]. The $\mathrm{f} / 2$ and MWC media are not very different in their nitrogen content, but the phosphorus content is higher in MWC than in $f / 2[50,51]$. The availability of phosphorus is reported to affect the fatty acid contents of algae, but the direction of the effect varies on genus level, and, for example, in diatoms, the phosphorus limitation increases the amount of total lipids, but decreases the PUFA content [17]. For testing the effects of nutrients, temperature and light, we should have cultured all strains in all conditions, including in culturing the saline strains in freshwater medium and vice versa, which would most probably have been impossible, and was also out of the scope of our study.

\section{Materials and Methods}

\subsection{Algal Culturing and Growth Rate Determinations}

The microalgal strains were acquired from culture collections (Table 1). We investigated altogether 17 strains. The starting point was the habitat of intermediate salinity, i.e., the brackish environment, and the strains were selected based on them being common and/or bloom-forming taxa and thus of ecosystem relevance in the northern Baltic Sea $\left(60^{\circ} \mathrm{N} 26^{\circ} \mathrm{E}\right)$. These species were as far as possible paired with marine and freshwater counterparts, selecting, whenever available, taxa of the same species, the same genus, or the same order. The selection process was affected by the availability of the strains in the culture collections, and the different character of the habitats, and ultimately our success in culturing them, thus not all strains had counterparts in all habitats. However, the selected strains included three strain pairs, i.e., species that originated in two different habitats. These were the diatoms Diatoma tenuis (brackish and freshwater strains) and Skeletonema marinoi (marine and brackish strains), and the dinoflagellate Apocalathium malmogiense (marine and brackish strains). The strains also included both potentially toxic and non-toxic species (Table 1).

All brackish water strains originated from the Baltic Sea. The brackish diatoms were cultured in $\mathrm{F} / 2$ medium [50] and the brackish dinoflagellates in F/2-Si, both based on 6 psu filtered $(0.2 \mu \mathrm{m})$ and autoclaved Baltic Sea seawater (FSW). The marine diatoms were likewise cultured in F/2 and the marine dinoflagellates in F/2-Si, both based on 30 psu FSW prepared using Tropic Marin ${ }^{\circledR}$ PRO-REEF artificial sea salt (Tropic Marin AG, Hünenberg, Switzerland) and the above mentioned Baltic Sea FSW. The culturing was done under a daily $16 \mathrm{~h}$ light: $8 \mathrm{~h}$ dark cycle at a light level of $115 \mu \mathrm{mol}$ quanta $\mathrm{s}^{-1} \mathrm{~m}^{-2}$. The temperature varied according to strain, but followed the temperatures given for each strain by the culture collections (Table 1). The strains were cultured in $550 \mathrm{~mL}$ plastic tissue culture flasks, five flasks per strain, giving a total of $2 \mathrm{~L}$ culture per strain. Two flasks per strain were sampled regularly (every two to seven days) to attain cell densities for growth rate calculation. The freshwater strains were cultured in MWC-medium [51] in $600 \mathrm{~mL}$ plastic tissue culture flasks. Each strain had two replicates, which were grown at $18{ }^{\circ} \mathrm{C}$ and under a $16 \mathrm{~h}$ light: $8 \mathrm{~h}$ dark cycle at a light level of $70 \mu \mathrm{mol}$ quanta s $\mathrm{m}^{-2}$. The culture conditions were not specifically optimized for growth or fatty acid production, but followed the instructions provided by the culture collections. The freshwater diatoms were sampled for cell number determinations every second day, but the growth rates were not determined for the freshwater dinoflagellates. Depending on culture, it took 15-30 days to attain the desired growth phase and cell density.

For growth rate calculations, the samples were preserved with acid Lugol's solution [52] and cell densities were counted using a Sedgewick-Rafter chamber (Paul Marienfeld GmbH \& Co. KG, Lauda-Königshofen, Germany). The specific growth rates $\left(\mu\right.$; divisions day $\left.{ }^{-1}\right)$ for all strains were calculated for the exponential growth phase using Equation 1:

$$
\mu=\ln (\text { cellsTx/cellsT0). }
$$




\subsection{Total Lipid Extraction, Fatty Acid Transesterification and Analysis by GC-MS}

The samples for fatty acid analyses were collected by centrifugation (2000 rpm for $10 \mathrm{~min}$ ) in the late exponential growth phase. The obtained pellets were placed into $-80{ }^{\circ} \mathrm{C}$ and freeze dried within a week. For the analysis, the total lipids were extracted from the freeze-dried samples no longer than four weeks after the sampling. Due to the low amount of biomass, we obtained only one sample from the brackish dinoflagellate $A$. malmogiense. Otherwise, two replicates of homogenized biomass samples (1-3 mg) were extracted using chloroform:methanol 2:1 (by volume). The samples were sonicated for $10 \mathrm{~min}$ to maximize extraction results, after which the samples were vortexed, and centrifuged for $5 \mathrm{~min}$ at $2000 \mathrm{rpm}$. Toluene and 1\% sulfuric acid in methanol were used for the transesterification of fatty acid methyl esters (FAME). We used 1,2-dinonadecanoyl-sn-glycero-3-phosphatidylcholine (Larodan, Solna, Sweden) and tricosanoic acid (Nu-Chek Prep Inc., Elysian, MN, USA) as internal standards. The samples were heated $\left(90^{\circ} \mathrm{C}\right.$ for $\left.90 \mathrm{~min}\right)$, after which they were neutralized with $1.5 \mathrm{~mL}$ of $2 \%$ of $\mathrm{KHCO}_{3}$ and diluted in $2 \mathrm{~mL}$ hexane. The tubes were vortexed and centrifuged $(2 \mathrm{~min}$ at $1500 \mathrm{rpm}$ ) and the upper layer was collected for the analysis.

FAMEs were analyzed with a gas chromatograph (Shimadzu Ultra, Kyoto, Japan) equipped with mass detector (GC-MS) and using helium as a carrier gas (linear velocity $=36.3 \mathrm{~cm} \mathrm{~s}^{-1}$ ). Temperature of injector was $270^{\circ} \mathrm{C}$ and we used splitless injection mode (for $1 \mathrm{~min}$ ). Temperatures of interface and ion source were $250^{\circ} \mathrm{C}$ and $220^{\circ} \mathrm{C}$, respectively. Phenomenex ${ }^{\circledR}$ (Torrance, CA, USA) ZB-FAME column $(30 \mathrm{~m} \times 0.25 \mathrm{~mm} \times 0.20 \mu \mathrm{m})$ with $5 \mathrm{~m}$ Guardian was used with the following temperature program: $50{ }^{\circ} \mathrm{C}$ was maintained for $1 \mathrm{~min}$, then the temperature was increased at $10^{\circ} \mathrm{C} \mathrm{min}^{-1}$ to $130{ }^{\circ} \mathrm{C}$, followed by $7{ }^{\circ} \mathrm{C} \mathrm{min}-1$ to $180^{\circ} \mathrm{C}$, and $2{ }^{\circ} \mathrm{C} \mathrm{min}-1$ to $200^{\circ} \mathrm{C}$ and held for $3 \mathrm{~min}$, and finally heated at $10^{\circ} \mathrm{C} \mathrm{min}^{-1}$ to $260^{\circ} \mathrm{C}$. Total program time was $35.14 \mathrm{~min}$ and solvent cut time $9 \mathrm{~min}$. Fatty acids were identified by the retention times (RT) and using specific ions [18], which were also used for quantification. Fatty acid concentrations were calculated using calibration curves based on known standard solutions (15 ng, $50 \mathrm{ng}, 100 \mathrm{ng}$ and $250 \mathrm{ng}$ ) of a FAME standard mixture (GLC standard mixture 566c, Nu-Chek Prep, Elysian, MN, USA) and using recovery percentage of internal standards. The Pearson correlation coefficient was $>0.99$ for each individual fatty acid calibration curve.

\subsection{Statistics}

The differences in the fatty acid contents (total fatty acids, $\omega-3$, combined ALA and SDA, OPA, EPA, DHA, $\omega-6$, LA, GLA, ARA, DPA) between the microalgal strains and habitats (marine, brackish and freshwater) were studied with ANOVA and Tukey's honestly significant difference (HSD) post hoc test. Levene's test was used for testing the homogeneity of variances. We used principal component analysis (PCA) ordinations for data visualization. Since PCA is not a statistical test, and the ANOVA tests only for the similarity of the group averages, we used PERMANOVA (permutational multivariate analysis of variance) and SIMPER (similarity percentages) for a more detailed study of the similarity of the fatty acid concentrations and proportional profiles of the diatoms and the dinoflagellates in the three habitats. PERMANOVA was run with unrestricted permutation of raw data and type III sums of squares. In statistical testing, $p$-values $<0.05$ were considered as statistically significant. The statistical analyses were performed using IBM SPSS Statistics 22 (SPSS Inc., Chicago, IL, USA), and the PCA, PERMANOVA and SIMPER were done using Primer 7 (version 7.0.13, Quest Research Limited, Auckland, New Zealand).

\section{Conclusions}

We hypothesized that phylogeny is the main factor influencing the fatty acid profiles and contents of diatoms and dinoflagellates including the $\omega-3$ and $\omega-6$. However, this was true only partly: when the fatty acid profiles were considered, the proportional differences in the fatty acids were explained by taxonomy, whereas the actual fatty acid concentrations were more related to the habitat than to phylogeny. Based on the strains studied, the fatty acid concentrations were systematically highest 
in the strains originating from freshwater. We also found that the proportional fatty acid profiles of the marine and the brackish diatoms and dinoflagellates were more similar to each other than to their freshwater counterparts. Nevertheless, the diatoms always had higher EPA than DHA and the dinoflagellates higher DHA than EPA concentrations, irrespective of the habitat. From the studied three strain pairs, we found significant habitat-related differences in Diatoma tenuis and Apocalathium malmogiense. Altogether, our results imply that the freshwater food webs may be richer in $\omega-3$ PUFAs than the marine and brackish food webs. However, more data is needed to draw definite conclusions.

The most promising diatom strain for commercial EPA production turned out to be the freshwater Nitzschia sp., whereas the highest DHA content was detected in the freshwater dinoflagellate Gymnodinium fuscum. This dinoflagellate also had a high total fatty acid and total $\omega-3$ PUFA content. Based on their $\omega-6: 3$-ratios, all of the studied strains are potentially suitable for products targeted to lower the $\omega-6: 3$-ratios of the Western diet. We did not study the toxicity of the strains but are aware that many microalgal species are known to produce toxins. Thus, as with all novel food and feed products, the safety of any microalgal strain needs to be guaranteed and legally certified before possible commercialization.

Supplementary Materials: The following are available online at http://www.mdpi.com/1660-3397/17/4/233/s1, Table S1: The fatty acid profiles of the studied strains.

Author Contributions: Conceptualization, E.P. and S.J.T.; Data curation, S.J.T.; Formal analysis, S.J.T.; Methodology, H.H. and S.J.T;; Resources, Elina Peltomaa, H.H. and S.J.T;; Validation, E.P. and S.J.T.; Writing-original draft, E.P.; Writing — review and editing, H.H. and S.J.T.

Funding: This research was funded by the Finnish Cultural Foundation research grant awarded to Elina Peltomaa.

Acknowledgments: The authors are grateful to Anke Kremp, Leibniz Institute for Baltic Sea Research, for her valuable advice and comments, and also to the three reviewers, whose dedicated comments helped to improve our manuscript significantly. The study utilized the Finnish Environment Institute Marine Research Centre marine research infrastructure as a part of the national FINMARI RI consortium.

Conflicts of Interest: The authors declare no conflict of interest. The funders had no role in the design of the study; in the collection, analyses, or interpretation of data; in the writing of the manuscript, or in the decision to publish the results.

\section{References}

1. Matos, J.; Cardoso, C.; Bandarra, N.M.; Afonso, C. Microalgae as healthy ingredients for functionalfood: A review. Food Funct. 2017, 8, 2672. [CrossRef] [PubMed]

2. Twining, C.W.; Brenna, J.T.; Hairston, N.G.; Flecker, A.S. Highly unsaturated fatty acids in nature: What we know and what we need to learn. Oikos 2016, 125, 749-760. [CrossRef]

3. Tocher, D.R.; Betancor, M.B.; Sprague, M.; Olsen, R.E.; Napier, J.A. $\Omega-3$ Long-Chain Polyunsaturated Fatty Acids, EPA and DHA: Bridging the Gap between Supply and Demand. Nutrients 2019, 11, 89. [CrossRef] [PubMed]

4. Calder, P.C. $\Omega-3$ polyunsaturated fatty acids and inflammatory processes: Nutrition or pharmacology? Br. J. Clin. Pharmacol. 2013, 75, 645-662. [CrossRef]

5. Patterson, E.; Wall, R.; Fitzgerald, G.F.; Ross, R.P.; Stanton, C. Health implications of high dietary $\omega-6$ polyunsaturated Fatty acids. J. Nutr. Metab. 2012, 2012, 539426. [CrossRef]

6. Kaur, N.; Chugh, V.; Gupta, A.K. Essential fatty acids as functional components of foods-A review. J. Food Sci. Technol. 2014, 51, 2289. [CrossRef]

7. Chen, M.; Liu, H.; Chen, B. Effects of dietary essential fatty acids on reproduction rates of subtropical calanoid copepod, Acartia erythraea. Mar. Ecol. Prog. Ser. 2012, 455, 95-110. [CrossRef]

8. Jonasdottir, S.H. Effects of food quality on the reproductive success of Acartia tonsa and Acartia hudsonica-laboratory observations. Mar. Biol. 1994, 121, 67-81. [CrossRef] 
9. Peltomaa, E.T.; Aalto, S.L.; Vuorio, K.M.; Taipale, S.J. The importance of phytoplankton biomolecule availability for secondary production. Front. Ecol. Evol. 2017, 5, 128. [CrossRef]

10. Taipale, S.J.; Kahilainen, K.K.; Holtgrieve, G.W.; Peltomaa, E.T. Simulated eutrophication and browning alters zooplankton nutritional quality and determines juvenile fish growth and survival. Ecol. Evol. 2018, 8, 2671-2687. [CrossRef] [PubMed]

11. Hixson, S.M.; Sharma, B.; Kainz, M.J.; Wacker, A.; Arts, M.T. Production, distribution, and abundance of long chain $\omega-3$ polyunsaturated fatty acids: A fundamental dichotomy between freshwater and terrestrial ecosystems. Environ. Rev. 2015, 23, 414-424. [CrossRef]

12. Burdge, G.C.; Calder, P.C. Conversion of $\alpha$-linolenic acid to longer-chain polyunsaturated fatty acids in human adults. Reprod. Nutr. Dev. 2005, 45, 581-597. [CrossRef]

13. Domenichiello, A.; Kitson, A.P.; Bazinet, R.B. Is docosahexaenoic acid synthesis from a-linolenic acid sufficient to supply the adult brain? Prog. Lipid Res. 2015, 59, 54-66. [CrossRef] [PubMed]

14. Ahlgren, G.; Gustafsson, I.-B.; Boberg, M. Fatty acid content and chemical composition of freshwater microalgae. J. Phycol. 1992, 28, 37-50. [CrossRef]

15. Taipale, S.; Strandberg, U.; Peltomaa, E.; Galloway, A.W.E.; Ojala, A.; Brett, M.T. Fatty acid composition as biomarkers of freshwater microalgae: Analysis of 37 strains of microalgae in 22 genera and in 7 classes. Aquat. Microb. Ecol. 2013, 71, 165-178. [CrossRef]

16. Galloway, A.W.E.; Winder, M. Partitioning the Relative Importance of Phylogeny and Environmental Conditions on Phytoplankton Fatty Acids. PLoS ONE 2015, 10, e0130053. [CrossRef]

17. Jónasdóttir, S.H. Fatty Acid Profiles and Production in Marine Phytoplankton. Mar. Drugs 2019, $17,151$. [CrossRef]

18. Taipale, S.J.; Vuorio, K.; Strandberg, U.; Kahilainen, K.K.; Järvinen, M.; Hiltunen, M.; Peltomaa, E.; Kankaala, P. Lake eutrophication and brownification downgrade availability and transfer of essential fatty acids for human consumption. Environ. Int. 2016, 96, 156-166. [CrossRef] [PubMed]

19. Brett, M.T.; Müller-Navarra, D.C.; Ballantyne, A.P.; Ravet, J.L.; Goldman, C.R. Daphnia fatty acid composition reflects that of their diet. Limnol. Oceanogr. 2006, 51, 2428-2437. [CrossRef]

20. Simopoulos, A.P. The importance of the $\omega-6 / \omega-3$ fatty acid ratio in cardiovascular disease and other chronic diseases. Exp. Biol. Med. (Maywood) 2008, 233, 674-688. [CrossRef]

21. Brown, M.R.; Jefferey, S.W.; Volkman, J.K.; Dunstan, G.A. Nutritional properties of microalgae for mariculture. Aquaculture 1997, 151, 315-331. [CrossRef]

22. Ryckebosch, E.; Muylaert, K.; Foubert, I. Optimization of an analytical procedure for extraction of lipids from microalgae. J. Am. Oil Chem. Soc. 2012, 89, 189-198. [CrossRef]

23. Anderson, B.M.; Ma, D.W. Are all n-3 polyunsaturated fatty acids created equal? Lipids Health Dis. 2009, 8, 33. [CrossRef]

24. Molendi-Coste, O.; Legry, V.; Leclercq, I.A. Why and how meet n-3 PUFA dietary recommendations? Gastroenterol. Res. Pract. 2011. [CrossRef]

25. Simopoulos, A.P. An Increase in the $\Omega-6 / \Omega-3$ Fatty Acid Ratio Increases the Risk for Obesity. Nutrients 2016, 8, 128. [CrossRef] [PubMed]

26. Gester, H. Can adults adequately convert alpha-linolenic acid (18:3n-3) to eicosapentaenoic acid (20:5n-3) and docosahexaenoic acid (22:6n-3)? Int. J. Vitam. Nutr. Res. 1998, 68, 159-173.

27. Peltomaa, E.; Johnson, M.D.; Taipale, S.J. Marine Cryptophytes Are Great Sources of EPA and DHA. Mar. Drugs 2018, 16, 3. [CrossRef]

28. FAO. The State of World Fisheries and Aquaculture 2018-Meeting the Sustainable Development Goals; FAO: Rome, Italy, 2018.

29. Turchini, G.M.; Ng, W.K.; Tocher, D.R. (Eds.) Fish Oil Replacement and Alternative Lipid Sources in Aquaculture Feeds; Taylor \& Francis, CRC Press: Boca Raton, FL, USA, 2011; p. 533. ISBN 9781439808627.

30. De Roos, B.; Sneddon, A.A.; Sprague, M.; Horgan, G.W.; Brouwer, I.A. The potential impact of compositional changes in farmed fish on its health-giving properties: Is it time to reconsider current dietary recommendations? Public Health Nutr. 2017, 20, 2042-2049. [CrossRef]

31. Sprague, M.; Dick, J.R.; Tocher, D.R. Impact of sustainable feeds on $\omega$-3 long-chain fatty acid levels in farmed Atlantic salmon, 2006-2015. Sci. Rep. 2016, 6, 21892. [CrossRef] 
32. Hallegraeff, G.M. Harmful algal blooms: A global overview. Man. Harmful Mar. Microalgae 2003, 33, 1-22.

33. Khan, M.I.; Shin, J.H.; Kim, J.D. The promising future of microalgae: Current status, challenges, and optimization of a sustainable and renewable industry for biofuels, feed, and other products. Microb. Cell Fact. 2018, 17, 36. [CrossRef]

34. Bolen, P.; van Dijk, R.; Sinninghe Damsté, J.P.; Rijpstra, W.I.C.; Buma, A.G.J. On the potential application of polar and temperate marine microalgae for EPA and DHA production. AMB Express 2013, 3, 26. [CrossRef] [PubMed]

35. Huerliman, R.; de Nys, R.; Hiemann, K. Growth, lipid content, productivity, and fatty acid composition of tropical microalgae for scale-up production. Biotechnol. Bioeng. 2010, 107, 245-257. [CrossRef] [PubMed]

36. Ma, X.-N.; Chen, T.-P.; Yang, B.; Liu, J.; Chen, F. Lipid Production from Nannochloropsis. Mar. Drugs 2016, 14, 61. [CrossRef]

37. Bates, S.S.; Bird, C.J.; Freitas, A.D.; Foxall, R.; Gilgan, M.; Hanic, L.A.; Johnson, G.R.; McCulloch, A.W.; Odense, P.; Pocklington, R.; et al. Pennate diatom Nitzschia pungens as the primary source of domoic acid, a toxin in shellfish from eastern Prince Edward Island, Canada. Can. J. Fish. Aquat. Sci. 1989, 46, 1203-1215. [CrossRef]

38. Paerl, H.W.; Fulton, R.S.; Moisander, P.H.; Dyble, J. Harmful Freshwater Algal Blooms, With an Emphasis on Cyanobacteria. Sci. World J. 2001, 1, 76-113. [CrossRef] [PubMed]

39. Hällfors, S. 2007: Annex 6: Potentially Harmful Phytoplankton Species of the Baltic Sea. In ICES WGGIB Report 2007, Proceedings of the ICES-IOC-SCOR Working Group on GEOHAB Implementation in the Baltic (WGGIB), Helsinki, Finland, 7-9 May 2007; ICES CM 2007/BCC:05; International Council for the Exploration of the Sea: Copenhagen, Denmark, 2007; pp. 21-28. Available online: http://ices.dk/sites/pub/Publication\% 20Reports/Expert\%20Group\%20Report/bcc/2007/wggib07.pdf (accessed on 15 March 2019).

40. Van Wagoner, R.M.; Deeds, J.R.; Satake, M.; Ribeiro, A.A.; Place, A.R.; Wright, J.L. Isolation and characterization of karlotoxin 1, a new amphipathic toxin from Karlodinium veneficum. Tetrahedron Lett. 2008, 49, 6457-6461. [CrossRef]

41. Kremp, A.; Tahvanainen, P.; Litaker, W.; Krock, B.; Suikkanen, S.; Leaw, C.P.; Tomas, C. Phylogenetic relationships, morphological variation, and toxin patterns in the Alexandrium ostenfeldii (Dinophyceae) complex: Implications for species boundaries and identities. J. Phycol. 2014, 50, 81-100. [CrossRef] [PubMed]

42. Moestrup, Ø.; Akselmann, R.; Fraga, S.; Hoppenrath, M.; Iwataki, M.; Komárek, J.; Larsen, J.; Lundholm, N.; Zingone, A. (2009 onwards). IOC-UNESCO Taxonomic Reference List of Harmful Micro Algae. Available online: http://www.marinespecies.org/hab (accessed on 15 March 2019).

43. Patil, V.; Källqvist, T.; Olsen, E.; Vogt, G.; Gislerød, H.R. Fatty acid composition of 12 microalgae for possible use in aquaculture feed. Aquacult. Int. 2007, 15, 1-9. [CrossRef]

44. Barofsky, A.; Simonelli, P.; Vidoudez, C.; Troedsson, C.; Nejstgaard, C.J.; Jakobsen, H.H.; Pohnert, G. Growth phase of the diatom Skeletonema marinoi influences the metabolic profile of the cells and the selective feeding of the copepod Calanus spp. J. Plankton Res. 2010, 32, 263-272. [CrossRef]

45. Sellem, F.; Pesando, D.; Bodennec, G.; El Abed, A.; Girard, J.-P. Toxic effects of Gymnodinium cf. mikimotoi unsaturated fatty acids to gametes and embryos of the sea urchin Paracentrotus lividus. Water Res. 2000, 34, 550-556. [CrossRef]

46. Fossat, B.; Porthe'-Nibelle, J.; Sola, F.; Masoni, A.; Gentien, P.; Bodennec, G. Toxicity of Fatty Acid 18:5n3 from Gymnodinium cf. mikimotoi: II. Intracellular $\mathrm{pH}$ and K1 Uptake in Isolated Trout Hepatocytes. J. Appl. Toxicol. 1999, 19, 275-278. [CrossRef]

47. Arzul, G.; Gentien, P.; Bodennec, G.; Toularastel, F.; Youenou, A.; Crassous, M.P. Comparison of toxic effects in Gymnodinium cf. nagasakiense polyunsaturated fatty acids. In Harmful Marine Algal Blooms; Lassus, P., Arzul, G., Erard, E., Gentien, P., Marcaillou, C., Eds.; Lavoisier Intercept: Paris, France, 1995; pp. 395-400.

48. Mooney, B.D.; Nichols, P.D.; de Salas, M.F.; Hallegraeff, G.M. Lipid, fatty acid, and sterol composition of eight species of Kareniaceae (Dinophyta): Chemotaxonomy and putative lipid phycotoxins. J. Phycol. 2007, 43, 101-111. [CrossRef]

49. Silva, G.; Pereira, R.B.; Valentão, P.; Andrade, P.B.; Sousa, C. Distinct fatty acid profile of ten brown macroalgae. Braz. J. Pharmacogn. 2013, 23, 608-613. [CrossRef]

50. Guillard, R.R.L.; Ryther, J.H. Studies of marine planktonic diatoms. I. Cyclotella nana Hustedt and Detonula confervacea Cleve. Can. J. Microbiol. 1962, 8, 229-239. [PubMed] 
51. Guillard, R.R.L.; Lorenzen, C.J. Yellowgreen algae with chlorophyllide. J. Phycol. 1972, 8, 10-14.

52. Willén, T. Studies on the phytoplankton of some lakes connected with or recently isolated from the Baltic. Oikos 1962, 13, 169-199. [CrossRef] 